\title{
ATP7B expression is associated with in vitro sensitivity to cisplatin in non-small cell lung cancer
}

\author{
YOSHIMASA INOUE ${ }^{1}$, HOZUMI MATSUMOTO ${ }^{2}$, SHUNSUKE YAMADA ${ }^{1}$, KENJI KAWAI $^{2}$, HIROSHI SUEMIZU $^{2}$, \\ MASATOSHI GIKA $^{3}$, IWAO TAKANAMI ${ }^{4}$, MASATO NAKAMURA ${ }^{5}$ and MASAYUKI IWAZAKI ${ }^{6}$

\begin{abstract}
${ }^{1}$ Department of General Thoracic Surgery, Tokai University Hachioji Hospital, Tokyo 192-0032; ${ }^{2}$ Central Institute for Experimental Animals, Kanagawa 216-0003; ${ }^{3}$ Department of General Thoracic Surgery, Saitama Medical Center, Saitama 350-8550; ${ }^{4}$ Department of Surgery, Teikyo University School of Medicine, Tokyo 173-8605; Departments of

${ }^{5}$ General Thoracic Surgery and ${ }^{6}$ Pathology, Tokai University School of Medicine, Kanagawa 259-1193, Japan
\end{abstract}

Received June 15, 2009; Accepted August 31, 2009

DOI: 10.3892/ol_00000049

\begin{abstract}
Copper-transporting P-type adenosine triphosphatase (ATP7B) is reportedly associated with platinum drug resistance in various solid tumors. However, the impact of ATP7B on platinum drug resistance in non-small cell lung cancer (NSCLC) remains unclear. We investigated in vitro cisplatin (CDDP) sensitivity using the collagen gel-droplet embedded culture drug sensitivity test. The ATP7B mRNA expression level in each specimen was also examined using real-time polymerase chain reaction. The relationship between ATP7B expression and in vitro CDDP sensitivity was then evaluated. The ATP7B mRNA expression levels in CDDPresistant tumors were significantly higher than those in the CDDP-sensitive group ( $\mathrm{p}=0.015$; Mann-Whitney $\mathrm{U}$ test $)$. Our results suggested that ATP7B expression is a promising chemoresistance marker for cisplatin.
\end{abstract}

\section{Introduction}

The anticancer drug cisplatin (CDDP), which contains platinum, is widely used for the treatment of solid tumors such as testicular, ovarian, cervical, bladder, head and neck, as well as non-small cell lung cancer (NSCLC) (1). CDDP has been a key drug in chemotherapy against NSCLC for more than 20 years.

Correspondence to: Dr Yoshimasa Inoue, Department of General Thoracic Surgery, Tokai University Hachioji Hospital, 1838 Ishikawa-cho, Hachioji, Tokyo 192-0032, Japan

E-mail: yoshimas@is.icc.u-tokai.ac.jp

Abbreviations: CDDP, cisplatin; ATP7B, copper-transporting P-type adenosine triphosphatase; CD-DST, collagen gel-droplet embedded culture drug sensitivity test; PCR, polymerase chain reaction; GIR, growth inhibition rate

Key words: non-small cell lung cancer, chemosensitivity, coppertransporting P-type adenosine triphosphatase, cisplatin, collagen gel-droplet embedded culture drug sensitivity test
However, the overall response rate to cisplatin as a single agent against NSCLC is no more than $20 \%$ (2). Furthermore, the development of resistance to CDDP is common during treatment of NSCLC patients, and is an important concern for clinical oncologists. Thus, exploring chemoresistance markers is significant. Mechanisms of CDDP resistance include a decrease in drug accumulation and enhanced detoxification, but an increase in DNA repair efficiency. However, studies are mainly limited to in vitro or in vivo experiments and none of the examined markers have been validated as common contributors to clinical CDDP resistance or the prognosis of patients with NSCLC (3).

Copper-transporting P-type adenosine triphosphatase (ATP7B) plays a key role in copper distribution inside cells. ATP7B is expressed in liver and kidney and, to a lesser extent, in the brain in normal individuals $(4,5)$. ATP7B is responsible for the export of copper from the liver; thus, mutations that disable the function of ATP7B may lead to excessive hepatic copper accumulation, as suggested by the impairment of biliary copper excretion in patients with Wilson disease (6). Previous studies suggested that the copper export system functions as efflux transporters for platinum drugs. Moreover, the immunohistochemical expression of ATP7B has been shown to be associated with resistance to platinum drugs in certain solid tumors (3,7-9). However, the expression of ATP7B and its impact on CDDP resistance in NSCLC have yet to be thoroughly investigated.

This study aimed to investigate the predictive value of ATP7B gene expression on in vitro chemosensitivity to CDDP, using surgically resected specimens from patients with NSCLC.

\section{Materials and methods}

Study population. Eligible patients included those with a histological diagnosis of NSCLC. These patients had not received chemotherapy nor radiotherapy and had undergone surgical resection. Patient specimens were tested using a chemosensitivity test. The study was conducted between 2005 and 2007 at Teikyo University Hospital and Tokai University Hospital. 
Eligible patients gave their informed consent. The patients consisted of 16 men and 5 women, ranging in age from 54 to 79 years (mean 68). Nine tumors were confirmed to be adenocarcinomas; eight, squamous cell carcinomas; three, large-cell carcinomas and one was confirmed to be poorly differentiated NSCLC.

In vitro chemosensitivity test. In vitro chemosensitivity was examined using the collagen gel-droplet embedded culture drug sensitivity test (CD-DST), as previously described by Kobayashi et al, with minor modifications (10-13). Briefly, surgically resected specimens were finely minced using a scalpel and digested in a cell dispersion enzyme solution EZ (Nitta Gelatin Inc.). The dispersed cancer cells were washed and filtered through a nylon mesh with a pore size of $200 \mathrm{~mm}$, collected by centrifugation, suspended in PCM-1 medium (Nitta Gelatin Inc.) and incubated in a $\mathrm{CO}_{2}$ incubator at $37^{\circ} \mathrm{C}$ for $24 \mathrm{~h}$. Viable cells were collected and re-suspended in reconstructed type I collagen solution with a final density of $1 \times 10^{5}$ cells $/ \mathrm{ml}$. Three drops of the collagen-cell mixture (30 ml/drop) were placed in each well of a 6-well multiplate and allowed to gel at $37^{\circ} \mathrm{C}$ overnight. Cisplatin (Bristol-Myers Squibb Inc.) was then added at a final concentration of $2 \mathrm{mg} / \mathrm{ml}$ and the plates were incubated for $24 \mathrm{~h}$. After removal of the medium containing the anticancer drugs, each well was rinsed twice, overlaid with PCM-2 medium (Nitta Gelatin Inc.) and incubated for 7 days. At the end of the incubation period, the colonies were stained with neutral red $(50 \mathrm{mg} / \mathrm{m}$ for $3 \mathrm{~h})$. Each collagen droplet was then fixed with $10 \%$ neutral formalin buffer, washed in water, air dried and quantified using imaging analysis. In vitro sensitivity was expressed as the growth inhibition rate (GIR): $(1-\mathrm{T} / \mathrm{C}) \times 100(\%)$, where $\mathrm{T}$ is the total volume of the treated group and $\mathrm{C}$ is the total volume of the control group.

In this study, each tumor was judged as 'resistant' when GIR was $\leq 60 \%$ and 'sensitive' when GIR was $>60 \%$.

Cell line. A human colorectal cancer cell line (HCT8) was obtained from Riken (Saitama, Japan). The cell line was cultured at $37^{\circ} \mathrm{C}$ in Dulbecco's modified Eagle's medium (containing $10 \%$ bovine serum) under a $5 \%$ atmosphere.

Quantitative evaluation of ATP7B mRNA expression. Total RNA was extracted from the tumor samples and a cell line using the acid guanidinium thiocyanate-phenol-chloroform extraction method. Complementary DNA (cDNA) was synthesized from $1 \mu \mathrm{g}$ of total RNA, according to our previous reports (14-16).

Real-time PCR assays were run on an ABI PRISM 7000 Sequence Detection System (Perkin-Elmer Applied Biosystems) according to the manufacturer's recommendations, as well as the recommendations of previously published studies. Briefly, a total volume of $50 \mu \mathrm{l}$ of reaction mixture containing $1 \mu \mathrm{l}$ of cDNA template, $25 \mu \mathrm{l}$ of TaqMan Universal PCR Master Mix (Perkin-Elmer Applied Biosystems) and $2.5 \mu \mathrm{l}$ of primer probe mixture for ATP7B and $\beta$-actin were amplified. The protocol used was: after the initial denaturation $\left(2 \mathrm{~min}\right.$ at $\left.95^{\circ} \mathrm{C}\right)$, amplification was performed for 50 cycles for $15 \mathrm{sec}$ at $95^{\circ} \mathrm{C}$ and $60 \mathrm{sec}$ at $60^{\circ} \mathrm{C}$. The primer probe mixture for ATP7B (Taqman ${ }^{\circledR}$ Gene Expression Assays, assay ID: Hs00163739_m1) and $\beta$-actin (human ACTB, 4310881E; both
Table I. Relationship between in vitro CDDP sensitivity and patient characteristics.

\begin{tabular}{lccc}
\hline & \multicolumn{2}{c}{ In vitro CDDP sensitivity $^{\mathrm{a}}$} & \\
\cline { 2 - 3 } Characteristics & $\mathrm{R}$ & $\mathrm{S}$ & P-value $^{\mathrm{b}}$ \\
\hline Age (mean \pm SD, years) & $69 \pm 7$ & $67 \pm 8$ & 0.60 \\
Gender & & & \\
Male & 8 & 8 & 0.20 \\
Female & 4 & 1 & \\
Histology & & & \\
Ad & 7 & 2 & 0.09 \\
Sq & 2 & 6 & \\
Other & 3 & 1 & \\
\hline
\end{tabular}

an vitro CDDP sensitivity. 'PP-value, evaluated by the MannWhitney U or Fisher's exact test, as appropriate. R, resistant; S, sensitive; Ad, adenocarcinoma; Sq, squamous cell carcinoma; Other, other histological subtypes (large-cell carcinoma and poorly differentiated carcinoma).

from Perkin-Elmer Applied Biosystems) were purchased as part of the commercial provider's kit.

To quantify the ATP7B gene transcripts precisely, we used the $\beta$-actin transcripts as a quantitative control and each sample was normalized based on its $\beta$-actin transcript content. Standard curves for ATP7B and $\beta$-actin mRNA were generated using serially diluted solutions $(1 / 5,1 / 25,1 / 125$ and $1 / 625)$ of HCT 8 cDNA. The threshold cycle $(\mathrm{Ct})$ was defined as the PCR cycle number at which point the fluorescent intensity exceeded the threshold. Following the determination of $\mathrm{Ct}$, the amount of target gene expression was calculated using the standard curve. Quantitative normalization of cDNA was performed in each sample using the expression of the $\beta$-actin gene as an internal control. Finally, the ATP7B mRNA levels were shown as a ratio of the $\beta$-actin mRNA levels. Real-time PCR assays were conducted in duplicate on one dish for each sample and the mean value was used to calculate the mRNA expression levels.

Statistical analysis. Categorical variables were analyzed using Fisher's exact test. Continuous variables were compared using the Mann-Whitney U test. Reported P-values were two-sided; $\mathrm{P}<0.05$ was considered to be statistically significant.

\section{Results}

In vitro chemosensitivity test. GIR values ranged from 0 to $68.6 \%$ (mean $\pm \mathrm{SD}, 38 \pm 18.4 \%$ ). According to the protocol described in Materials and methods, 12 tumors were judged to be 'resistant (R)' to CDDP, while 9 other tumors were judged to be 'sensitive (S)' to CDDP.

No significant correlation was observed between in vitro CDDP sensitivity and any of the clinical parameters including age, gender and histology (Table I). 
Table II. Relationship between ATP7B mRNA expression levels and patient characteristics.

\begin{tabular}{lll}
\hline Characteristics & $\begin{array}{c}\text { Mean ATP7B gene } \\
\text { expression level } \pm \text { SD }\end{array}$ & P-value $^{\mathrm{a}}$
\end{tabular}

Age

$\begin{array}{llc}>70 & 0.14 \pm 0.12 & 0.70 \\ \leq 70 & 0.17 \pm 0.17 & \\ \text { Gender } & & \\ \text { Male } & 0.11 \pm 0.09 & 0.13 \\ \text { Female } & 0.30 \pm 0.18 & \\ \text { Histology } & & 0.01 \\ \text { Ad } & 0.26 \pm 0.17 & \\ \text { Non-Ad } & 0.09 \pm 0.08 & \end{array}$

aP-value, evaluated by the Mann-Whitney U or Turkey-Kramer test, as appropriate. SD, standard deviation; Ad, adenocarcinoma; non-Ad, non-adenocarcinoma (i.e., squamous cell carcinoma, large-cell carcinoma and poorly differentiated NCSLC).

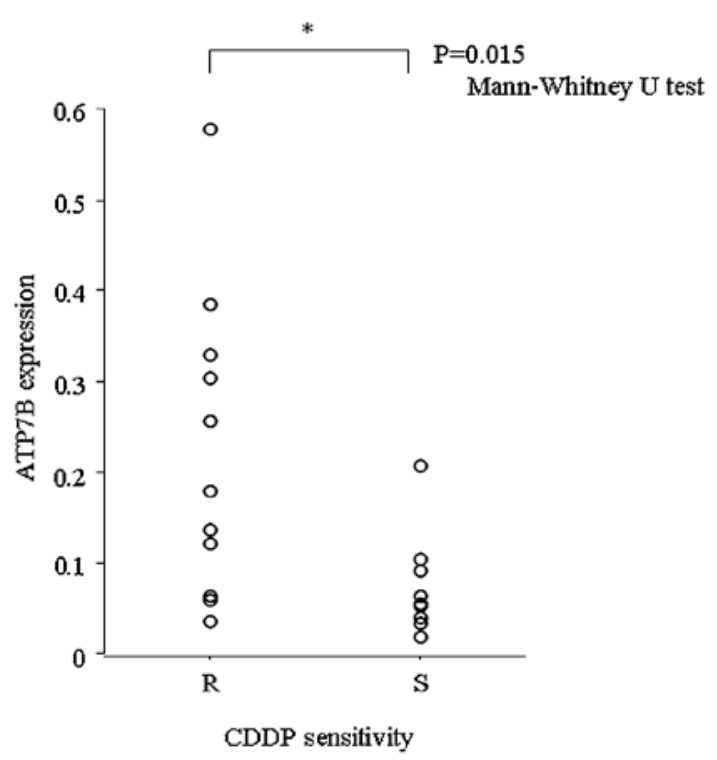

Figure 1. ATP7B mRNA expression level and in vitro cisplatin sensitivity.

ATP7B mRNA expression. The ATP7B mRNA expression levels varied from 0.02 to 0.57 (mean $\pm \mathrm{SD}, 0.15 \pm 0.14$ ). The relationship between the ATP7B expression levels and clinical parameters, including age, gender and histology, are summarized in Table II. No significant correlation was observed between the ATP7B mRNA expression levels and age or gender $(\mathrm{P}=0.7$ and $\mathrm{P}=0.13$, respectively; Mann-Whitney $\mathrm{U}$ test).

ATP7B gene expression in the adenocarcinoma group was significantly higher than that in the non-adenocarcinoma group ( $\mathrm{p}=0.01$; Mann-Whitney U test).

Relationship between $A T P 7 B$ expression and CDDP sensitivity. The difference in ATP7B expression between the
CDDP-resistant ( $\mathrm{R}$ group, $\mathrm{n}=12$ ) and CDDP-sensitive tumors (S group, $n=9$ ) was evaluated. The ATP7B mRNA expression levels in the $\mathrm{R}$ group were significantly higher than those in the $S$ group ( $p=0.015$; Mann-Whitney U test; Fig. 1).

\section{Discussion}

This study investigated the association between ATP7B mRNA expression and in vitro chemosensitivity to CDDP using surgically resected specimens of NSCLC. As a result, we observed that the CDDP-resistant tumors expressed a significantly higher level of ATP7B mRNA than the CDDPsensitive tumors.

ATP7B is a member of a class of heavy metal-transporting P-type ATPases that pump copper, cadmium, zinc, silver or lead $(7,17,18)$. Copper is an essential trace element and is transported to the extracellular environment by an energy-dependent system. Alterations in copper homeostasis can cause severe problems (18). For example, Wilson disease, an autosomal recessive disease of copper transport, is characterized by chronic liver and/or neurological disorders, occasionally accompanied by kidney damage $(19,20)$.

ATP7B mRNA expression was reported to be associated with in vitro cisplatin resistance in ovarian carcinoma cell lines (21). The transfection of epidermoid, head and neck and ovarian carcinoma cells with an ATP7B expression vector rendered them resistant to platinum drugs, such as cisplatin, carboplatin and oxaliplatin $(7,8,22)$. These ATP7B-transfected cells not only exhibited reduced intracellular concentrations, but also an increased efflux of these platinum drugs $(7,8)$.

The possible clinical significance of ATP7B expression was noted in various solid tumors. A higher expression level of ATP7B is correlated with an unfavorable response to platinum drug treatment in ovarian, esophageal and oral squamous cell carcinoma $(19,23,24)$. We recently reported that ATP7B mRNA and protein expression levels are associated with CDDP resistance in NSCLC xenografts (14). However, the expression of ATP7B in NSCLC tissues and its clinical significance have yet to be adequately studied.

Little is known about the differences in ATP7B expression levels according to the histological subtypes of NSCLC. In this study, the ATP7B expression level was found to be significantly higher in the adenocarcinoma than in the non-adenocarcinoma group. Further study is needed to confirm and clarify the clinicopathological significance of this observation.

In conclusion, although data presented were based only on an in vitro assay, our results suggest that ATP7B gene expression is correlated with CDDP resistance and that ATP7B expression is a useful chemoresistance marker for cisplatin.

\section{References}

1. Perez RP: Cellular and molecular determinants of cisplatin resistance. Eur J Cancer 34: 1535-1542, 1998.

2. Tiseo M, Franciosi V, Grossi F and Ardizzoni A: Adjuvant chemotherapy for non-small cell lung cancer: ready for clinical practice? Eur J Cancer 42: 8-16, 2006.

3. Katoh R, Takebayashi Y and Takenoshita S: Expression of copper-transporting P-type adenosine triphosphatase (ATP7B) as a chemoresistance marker in human solid carcinomas. Ann Thorac Cardiovasc Surg 11: 143-145, 2005.

4. Safaei R: Role of copper transporters in the uptake and efflux of platinum containing drugs. Cancer Lett 234: 34-39, 2006. 
5. Tanzi RE, Petrukhin K, Chernov I, et al: The Wilson disease gene is a copper transporting ATPase with homology to the Menkes disease gene. Nat Genet 5: 344-350, 1993.

6. Safaei R, Holzer AK, Katano K, Samimi G and Howell SB: The role of copper transporters in the development of resistance to $\mathrm{Pt}$ drugs. J Inorg Biochem 98: 1607-1613, 2004.

7. Komatsu M, Sumizawa T, Mutoh M, Chen ZS, Terada K, Furukawa T, Yang XL, Gao H, Miura N, Sugiyama T and Akiyama S: Copper-transporting P-type adenosine triphosphatase (ATP7B) is associated with cisplatin resistance. Cancer Res 60: 1312-1316, 2000

8. Katano K, Safaei R, Samimi G, Holzer A, Tomioka M, Goodman M and Howell SB: Confocal microscopic analysis of the interaction between cisplatin and the copper transporter ATP7B in human ovarian carcinoma cells. Clin Cancer Res 10: 4578-4588, 2004.

9. Nakayama K, Kanzaki A, Ogawa K, Miyazaki K, Neamati N and Takebayashi Y: Copper-transporting P-type adenosine triphosphatase (ATP7B) as a cisplatin based chemoresistance marker in ovarian carcinoma: comparative analysis with expression of MDR1, MRP1, MRP2, LRP and BCRP. Int J Cancer 101: 488-495, 2002.

10. Kobayashi H: Collagen gel droplet culture method to examine in vitro chemosensitivity. Methods Mol Med 110: 59-67, 2005.

11. Kobayashi H: Development of a new in vitro chemosensitivity test using collagen gel droplet embedded culture and image analysis for clinical usefulness. Recent Results Cancer Res 161: 48-61, 2003.

12. Inoue Y, Gika M, Abiko T, Oyama T, Saitoh Y, Yamazaki H, Nakamura M, Abe Y, Kawamura M and Kobayashi K: Bcl-2 overexpression enhances in vitro sensitivity against docetaxel in non-small cell lung cancer. Oncol Rep 13: 259-264, 2005.

13. Kawamura M, Gika M, Abiko T, Inoue Y, Oyama T, Izumi Y, Kobayashi $\mathrm{H}$ and Kobayashi K: Clinical evaluation of chemosensitivity testing for patients with unresectable non-small cell lung cancer (NSCLC) using collagen gel droplet embedded culture drug sensitivity test (CD-DST). Cancer Chemother Pharmacol 59: 507-513, 2007

14. Nakagawa T, Inoue Y, Kodama H, Yamazaki H, Kawai $K$, Suemizu H, Masuda R, Iwazaki M, Yamada S, Ueyama Y, Inoue H and Nakamura M: Expression of copper-transporting P-type adenosine triphosphatase (ATP7B) correlates with cisplatin resistance in human non-small cell lung cancer xenografts. Oncol Rep 20: 265-270, 2008.

15. Nishi M, Abe Y, Fujimori S, Hamamoto A, Inoue Y, Miyazaki N, Oida Y, Ikoma N, Ohnishi Y, Yamazaki H, Ueyama Y and Nakamura M: The modifier subunit of glutamate cysteine ligase relates to cisplatin resistance in human small-cell lung cancer xenografts in vivo. Oncol Rep 14: 421-424, 2005.
16. Fujimori S, Abe Y, Nishi M, Hamamoto A, Inoue Y, Ohnishi Y, Nishime C, Matsumoto H, Yamazaki H, Kijima H, Ueyama Y, Inoue $\mathrm{H}$ and Nakamura $\mathrm{M}$ : The subunits of glutamate cysteine ligase enhance cisplatin resistance in human non-small cell lung cancer xenografts in vivo. Int J Oncol 25: 413-418, 2004.

17. Terada K, Schilsky ML, Miura N and Sugiyama T: ATP7B (WND) protein. Int J Biochem Cell Biol 30: 1063-1067, 1998.

18. Harris ED, Qian Y, Tiffany-Castiglioni E, Lacy AR and Reddy MC: Functional analysis of copper homeostasis in cell culture models: a new perspective on internal copper transport. Am J Clin Nutr 67: 988-995, 1998.

19. Higashimoto M, Kanzaki A, Shimakawa T, Konno S, Naritaka Y, Nitta Y, Mori S, Shirata S, Yoshida A, Terada K, Sugiyama T, Ogawa K and Takebayashi Y: Expression of copper-transporting P-type adenosine triphosphatase in human esophageal carcinoma. Int J Mol Med 11: 337-341, 2003.

20. Petrukhin K, Lutsenko S, Chernov I, Ross BM, Kaplan JH and Gilliam TC: Characterization of the Wilson disease gene encoding a P-type copper transporting ATPase: genomic organization, alternative splicing, and structure/function predictions. Hum Mol Genet 3: 1647-1656, 1994

21. Nakayama K, Miyazaki K, Kanzaki A, Fukumoto M and Takebayashi Y: Expression and cisplatin sensitivity of coppertransporting P-type adenosine triphosphatase (ATP7B) in human solid carcinoma cell lines. Oncol Rep 8: 1285-1287, 2001.

22. Katano K, Safaei R, Samimi G, Holzer A, Rochdi M and Howell SB: The copper export pump ATP7B modulates the cellular pharmacology of carboplatin in ovarian carcinoma cells. Mol Pharmacol 64: 466-473, 2003.

23. Nakayama K, Kanzaki A, Terada K, Mutoh M, Ogawa K, Sugiyama T, Takenoshita S, Itoh K, Yaegashi N, Miyazaki K, Neamati $\mathrm{N}$ and Takebayashi Y: Prognostic value of the $\mathrm{Cu}$-transporting ATPase in ovarian carcinoma patients receiving cisplatin-based chemotherapy. Clin Cancer Res 10: 2804-2811, 2004.

24. Miyashita H, Nitta Y, Mori S, Kanzaki A, Nakayama K, Terada K, Sugiyama T, Kawamura H, Sato A, Morikawa H, Motegi K and Takebayashi Y: Expression of copper-transporting P-type adenosine triphosphatase (ATP7B) as a chemoresistance marker in human oral squamous cell carcinoma treated with cisplatin. Oral Oncol 39: 157-162, 2003. 